\title{
Amount and distribution of fume contaminants in the lungs of an arc welder post mortem
}

\author{
PIRKKO-LIISA KALLIOMÄKI ${ }^{1}$,S. SUTINEN ${ }^{2}$, V. KELHÄ ${ }^{3}$, \\ EEVA LAKOMAA ${ }^{3}$, V. SORTTI', AND SIRKKA SUTINEN ${ }^{2}$ \\ From the ${ }^{1}$ Institute of Occupational Health, Helsinki, the ${ }^{2}$ Department of Pathology, University of Oulu, \\ Oulu, and ${ }^{3}$ Technical Research Centre of Finland, Helsinki
}

\begin{abstract}
This study describes various post-mortem examinations of the lungs of a shipyard arc welder. These investigations comprised morphological methods, including gross pathology and radiography, histological and ultrastructural examinations, chemical analysis of lung tissue, and sensitive magnetic measurements, which can now be used to detect magnetic contaminants, such as welding fume, in human tissue. Such methods can also show the distribution of contaminants. The amount of welding-fume contaminants was low, only $110 \mathrm{mg}$. The contaminant iron seemed to represent only $10 \%$ of the total iron chemically analysed in lung tissue. The concentration of the total iron was 4-10 times higher than that in control tissue. Contaminants tended to collect in the central areas of the lungs. Two concentration centres could be observed in each lung, one anterior and one posterior. There was slight fibrosis around pigmented areas. Histological findings were similar to those of previous studies. Transmission electron micrographs showed that enlarged lysosomes of macrophages contained electron-dense granules, $450 \mathrm{~nm}$ to less than $5 \mathrm{~nm}$ in diameter, which formed aggregates and short chains, and resembled welding-fume particles in the breathing zone. Our results show the value of studying the same material by a number of inter-related methods.
\end{abstract}

Arc-welder's siderosis has been considered to be a benign form of pneumoconiosis because several early studies failed to show any tissue reaction to the inhaled iron oxide fumes (Enzer and Sander, 1938; Angervall et al., 1960). In recent years, however, several authors have presented evidence of more than slight fibrosis in the lungs of arc welders (Charr, 1955, 1956; Friede and Rachow, 1961; Morgan and Kerr, 1963; Slepička et al., 1970; Einbrodt et al., 1971; Buckup, 1973). Chemically coated electrodes have been in general use for almost three decades and the composition of electrode coatings has increased in complexity over the years. At present the fumes evolved during manual welding of mild steel contain many solid and gaseous materials, the health hazards of which are not fully known (Hewitt and Hicks, 1973).

In modern shipyards the concentration of solid particles in the breathing zone varies between 2 and Address for correspondence: Dr P.-L. Kalliomäki, Haart-
maninkatu 1, SF-00290 Helsinki 29, Finland.

Received for publication 17 April 1978

Accepted for publication 15 December 1978
$400 \mathrm{mg} / \mathrm{m}^{3}$ according to surveys made by the Institute of Occupational Health, Helsinki.

The composition of solid inorganic particles in welding fumes is dependent on the material being welded and the electrode. The elements copper, fluorine, iron, manganese, magnesium, nickel, silicon, titanium and zinc have been detected in manual arc welding fumes (Virtamo et al., 1975; Stern, 1976). However, the precise chemical compounds present in welding fumes are not fully known. The main components (about $25-70 \%$ ) are iron oxides, of which more than $90 \%$ is magnetite $\left(\mathrm{Fe}_{3} \mathrm{O}_{4}\right)$ (Virtamo et al., 1975; Stern, 1976). Silica occurs in welding fumes in an amorphous form.

The mass median diameter of welding-fume particles is about $0.5 \mu \mathrm{m}$ and the count median $0.05 \mu \mathrm{m}$. Transmission electron micrographs show that particles form long chains and rings: these particles have been described as polycrystalline, with an amorphous outer scale (Stern, 1976).

Conventional chemical analysis of lung tissue has shown a 15-100 times higher iron content in the lungs of welders than in those of unexposed subjects (Mann and Lecutier, 1957; Angervall et al., 1960; 
Morgan and Kerr, 1963; Meyer et al., 1967), but it has not been possible to distinguish exogenous (inhaled) iron from that of endogenous sources. Recently neutron activation analysis has been used to determine the composition of manual mild steel arc welding-fume contaminants in lung tissue (Hewitt and Hicks, 1973), and the electron microscope has been used to study the shape, size and chemical composition of stainless steel weldingfume contaminants in lung biopsies (Stettler et al., 1977). We have found no reports on size, shape, crystalline structure, amount and spatial distribution of manual mild steel arc welding-fume contaminants in lung tissue. We have now investigated these characteristics using morphological methods including gross pathology and histopathology, transmission electron microscopy, tissue radiography, chemical analysis of lung tissue, and magnetic measurements. The lung tissue was taken from the lungs of an arc welder post mortem.

\section{Material and methods}

MATERIAL

Both lungs of a 35-year-old male arc welder were studied by the methods described below. In addition, the left lung of a 72-year-old male flour miller was used as a reference in magnetic studies, and histological sections of the miller's right lung were also reviewed. The arc welder had worked for the last 11 years of his life in a shipyard, welding mild steel plates using mainly basic coated electrodes (Esab OK 48). From 10 to $20 \%$ of all electrodes used in the shipyard had been rutile. He had worked in the open air as well as in confined areas inside ships. $\mathrm{He}$ had never smoked and had been in good health without respiratory symptoms until he died suddenly of myocardial infarction. The miller had never done any kind of welding, but for the last 31 years of his life he had been the owner and operator of a small flour and saw mill, working in his mill until his final illness. He had smoked for a total of 50 years but stopped smoking 11 years before death. He died of cancer of the right lung with cerebral metastases.

\section{MORPHOLOGICAL METHODS}

The lungs of the arc welder (and the miller's left lung) were inflated intrabronchially with a $4 \%$ formaldehyde- $1 \%$ glutaraldehyde solution prepared with a 200 mosmol phosphate buffer (McDowell and Trump, 1976) and were left immersed in this solution for several days. Unfortunately, the lungs were not fully expanded.

After fixation the right lung was cut sagittally and the left coronally into slices approximately $1 \mathrm{~cm}$ thick, which were examined macroscopically and radiographed using mammographic methods. Tissue for light microscopy was embedded in paraffin, cut into sections $6 \mu \mathrm{m}$ thick and stained with haematoxylin and eosin, haematoxylin-van Gieson and Prussian blue. For transmission electron microscopy the tissue was postfixed in osmium tetroxide, dehydrated in alcohol and embedded in Epon. Thin sections were cut on an LKB Ultrotome III, stained with uranyl acetate and lead citrate, and examined in a Jeol 100 B electron microscope. Semi-thin sections were also made for light microscopy from Epon-embedded blocks. The miller's lung was sliced in the sagittal plane as described above.

\section{CHEMICAL ANALYSIS}

One slice (No. 2) from the right lung and four slices from the left lung (Nos. 2, 4, 6, 10) were subjected to chemical analysis. Neutron activation analysis was used to determine iron, zinc, nickel and chromium. The lung samples were freeze-dried, and $27-60 \mathrm{mg}$ portions of dried lung were sealed in quartz ampoules, as were standards containing iron, nickel, chromium and zinc. NBS bovine liver reference standard (SM 1577) was used to monitor the reliability of the analysis. The standards and samples were irradiated in the central thimble of a Triga Mark II reactor at the Reactor Laboratory, Technical Research Centre of Finland.

The detection limits for activation analysis determinations were calculated according to the methods of Curry (1968). Activation analysis, used in this study, is sensitive enough to allow zinc and iron in the lungs to be analysed.

Copper, magnesium and manganese were analysed by atomic absorption spectrometry using a Varian Techtron AA-5 spectrometer. Portions of the lung samples were digested in suprapure nitric acid and diluted with deionised water. NBS bovine liver standard, treated in the same way as the samples, was used to monitor the reliability of the method. The detection limits in analysing lung samples with atomic absorption spectrometry were $5 \mathrm{ppm}$ for copper, $3 \mathrm{ppm}$ for magnesium and $4 \mathrm{ppm}$ for manganese.

\section{PHYSICAL METHODS}

\section{Magnetic susceptibility measurement}

To determine the concentration of magnetic contaminants, the magnetic susceptibility of the lungs was measured by the Gouy method (Weissberger and Rossiter, 1972). An assumption is made that all the magnetic iron is present as magnetite, so any ferromagnetic free iron entering the lungs will cause a considerable error (Shandley and Bacon, 1966). The 
susceptibility of four slices (Nos. 2, 4, 6, 10) of the left lung and one slice of the unexposed reference lung were measured by this method. The magnetising field was $50 \mathrm{kA} / \mathrm{m}$, except in the reference $250 \mathrm{kA} / \mathrm{m}$ which therefore was analysed according to the combined Faraday-Gouy method (Laurila, 1976). The magnetite concentration was derived from the susceptibility measurements, using the demagnetising factor for the magnetic fume particles. This was determined from hysteresis and susceptibility measurements on the welding fume (Laurila, 1961).

\section{Measurement of permanent magnetic field}

The amount and distribution of welding-fume lung contaminants were measured by a method described by Cohen (1973, 1975), Kalliomäki et al. (1976, 1978) and Kalliomäki (1977). The method was based on the remanent magnetic field of welding-fume particles retained in the lungs. First, the lung tissue was magnetised in a low external magnetic field. Subsequently, the permanent field caused by ferromagnetic contaminants was mapped with a SQUID-type sensitive magnetometer, cooled with liquid helium.

Results were expressed as the average magnetic field, and the equivalent concentration of welding fumes in each slice. The calibration, i.e., the relation between the measured magnetic fields and the concentration of contaminants, was based on experimental studies of magnetic properties of welding fumes (Kalliomäki, 1977).

To determine the amount and distribution of magnetic contaminants in the lungs, the permanent fields which they created were mapped from the fixed whole lungs and from each slice.

When measuring slices, the lateral resolution of the method was about $40 \mathrm{~mm}$, enabling the distribution of contaminants to be determined in each slice. The measured permanent magnetic fields were converted to the amounts of welding-fume contaminants in each slice and in both lungs.

\section{Results}

\section{MORPHOLOGICAL STUDIES}

Gross pathology and radiography

On the cut surface of the lung slices there were large numbers of small brownish macules, measuring from less than one to as much as three millimetres in diameter. These were located in the centriacinar regions around terminal bronchioles. The radiographs of the slices (Fig. 1) showed small dense areas of the same size range and of irregular shape corresponding to the brownish areas seen macroscopically. These dense areas were most readily seen in the superior segment of the lower lobe and on both sides

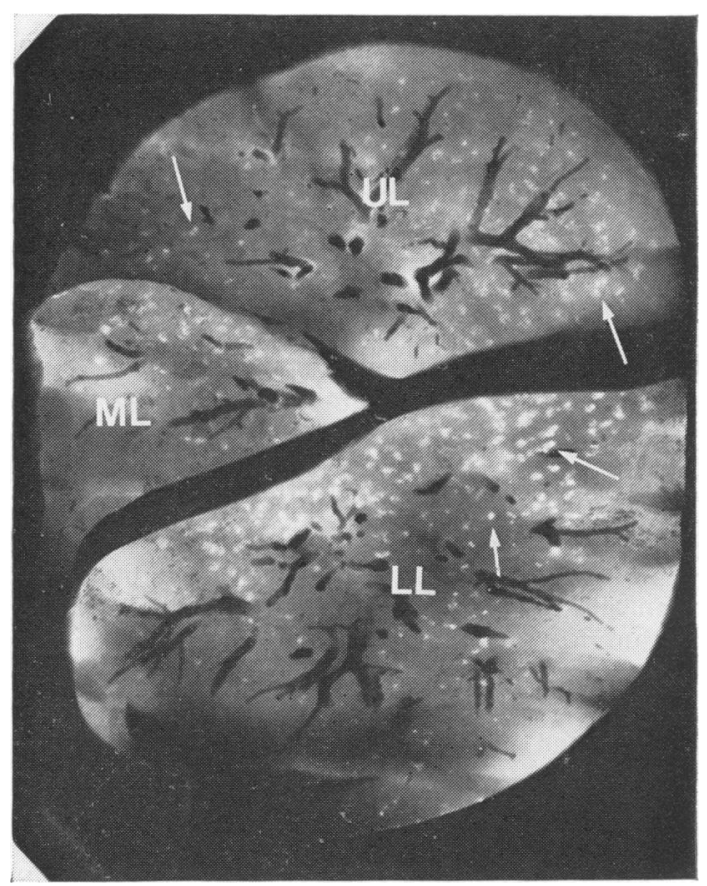

Fig. 1 Radiograph of a sagittal slice of right lung. Small white spots (arrows) represent deposits of radioopaque contaminant with accumulation in the central parts. $U L=$ upper lobe, $M L=$ middle lobe, $L L=$ lower lobe. Lung incompletely expanded.

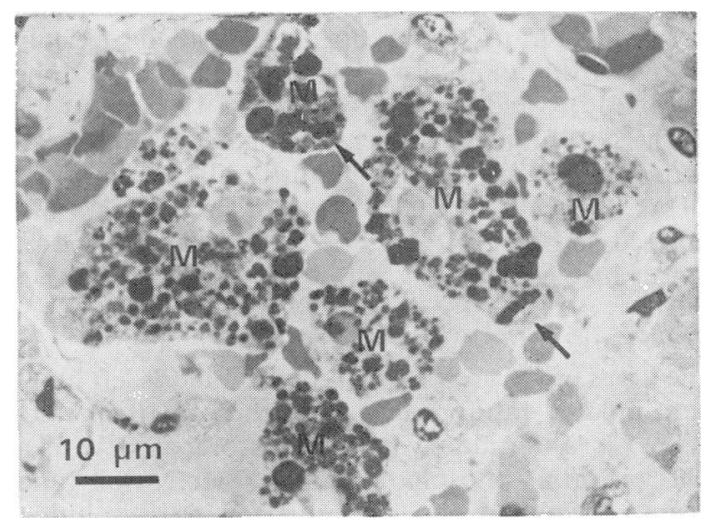

Fig. 2 Light micrograph of semi-thin section of lung tissue from grossly pigmented area. Alveolar macrophages $(M)$ contain numerous, mainly round pigment granules representing lysosomes and measuring $<0.5-6 \mu \mathrm{m}$ in diameter. Toluidine blue, $\times 1300$. 
of the interlobar fissure between upper and lower lobes in both lungs. No emphysema was present.

\section{Light microscopy}

Deposition of brown pigment, part of which gave a positive Prussian blue reaction, occurred in the air spaces, in the interstitium of alveolar septa, and in perivascular and peribronchial spaces. In air spaces the pigment was mainly in the macrophages whereas in the interstitium it sometimes seemed to be extracellular. A slight increase in fibrous tissue could be observed in the pigmented areas, but no changes suggesting emphysema could be observed. In addition a few asbestos bodies were found, most of them in the areas of larger pigment collections.

Semi-thin sections showed that the cytoplasm of the enlarged intra-alveolar macrophages was filled with roughly round pigment granules measuring from less than $0.5 \mu \mathrm{m}$ up to $6 \mu \mathrm{m}$ in diameter and apparently representing heterophagosomes (Fig. 2). Other phagosomes had an elongated shape. Many interstitial pigmented phagocytes were in the perivascular lymphatics.

\section{Transmission electron microscopy}

Electron micrographs of the mild steel manual arc welding fume showed roundish electron-dense particles of widely variable sizes (Figs. 3a, 4a, 5a). The largest globules, which are not illustrated, measured $18 \mu \mathrm{m}$ and the smallest granules (Fig. 4a) less than $5 \mathrm{~nm}$ in diameter. A portion of a large spherical particle is shown in Fig. 3a. Some of the particles with a diameter of $10-50 \mathrm{~nm}$ seemed to consist of smaller subunits (Figs. 4a, 5a).

The alveolar macrophages showed a large number of greatly enlarged lysosomes filled with electrondense granular material. The largest oval granules measured approximately $450 \mathrm{~nm}$ (Fig. 3b, black arrow) and the smallest ones less than $5 \mathrm{~nm}$ in diameter (Fig. 4b). Short chains of particles of different sizes could be seen (Figs. 4b, 5b). In addition, many lysosomes contained irregular holes measuring from $0.5 \times 3$ to $4.5 \times 11 \mu \mathrm{m}$, possibly where larger mineral particles had fallen out during sectioning.

When the electron micrographs of the welding fume (Figs. 3a, 4a, 5a) and those of alveolar macrophages (Figs. 3b, 4b, 5b) were compared with each other, the particles in each were strikingly similar. Even the arrangement in chains was preserved to some extent in the phagocytosed particles.

\section{RESULTS OF CHEMICAL ANALYSIS}

Table 1 shows the results of chemical analysis. The total iron concentration in the lung tissue of our welder was no more than ten times that in control tissue. The concentrations of chromium were just above the detection limit, and the concentrations of nickel were above the detection limit (6 ppm) in some of the lung slices.

\section{RESULTS OF PHYSICAL MEASUREMENTS}

\section{Magnetic susceptibility measurements}

The results of magnetic susceptibility measurements are shown in Table 2. The susceptibility and the magnetite concentration varied from $82 \times 10^{-6}$ to

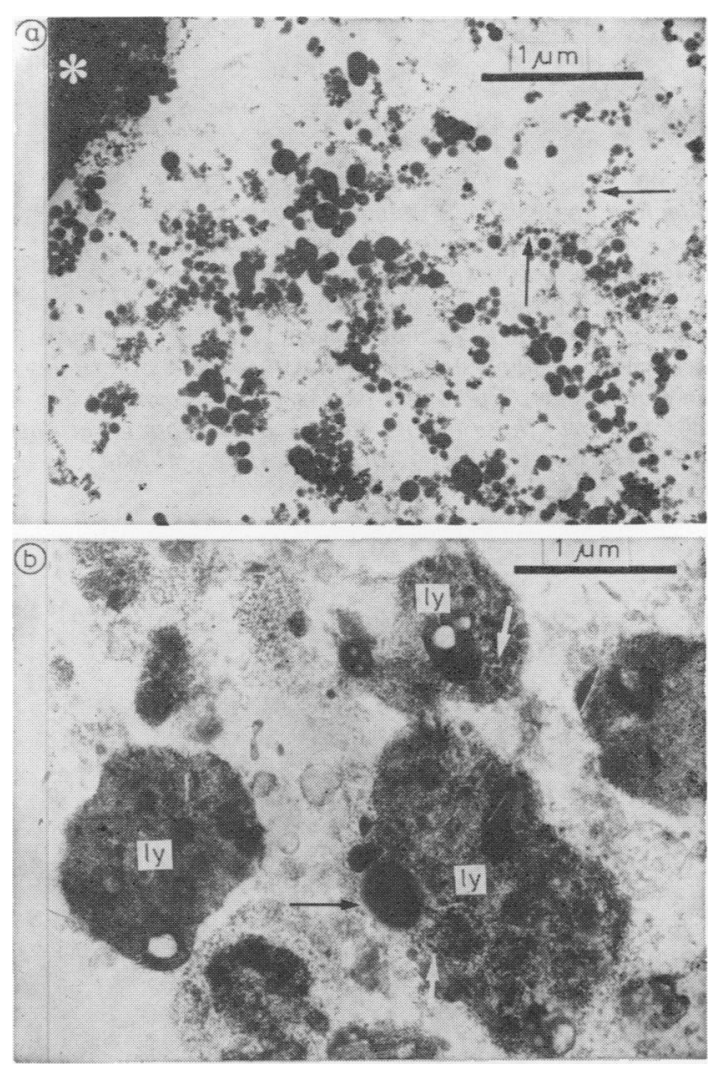

Fig. 3a Electron micrograph of welding fume. Part of a large globule, $7 \cdot 2 \mu \mathrm{m}$ in diameter, at upper left (asterisk). Smaller spherical particles are arranged in groups and chains (arrows). Still smaller particles are seen as background smudge. $\times 26500$.

Fig. 3b Electron micrograph showing part of an alveolar macrophage. Enlarged lysosomes $(l y)$ are filled with electron-dense granular material. The largest oval particle (black arrow) measures $450 \mathrm{~nm}$ in diameter. The smallest discernible particles (white arrows) in the midst of a finely granular background measure approximately $40 \mathrm{~nm}$ in diameter. Uranyl acetate and lead citrate, $\times 26500$. 

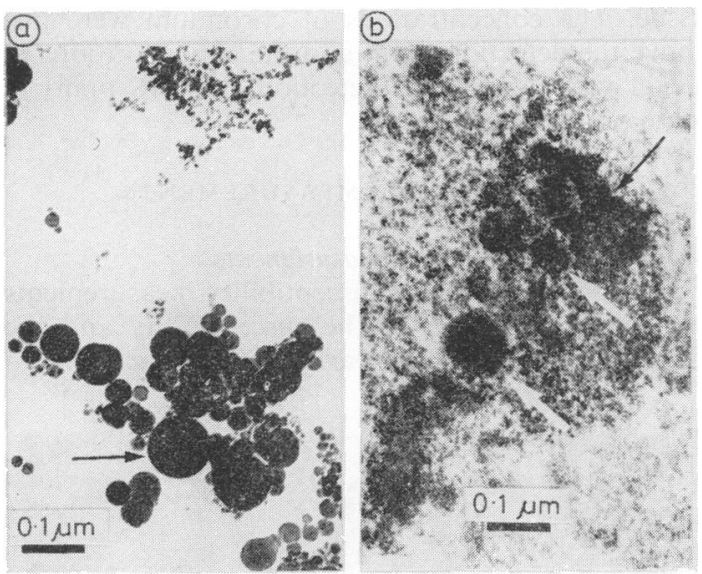

Fig. 4a Electron micrograph of welding fume. A collection of very small granules, several with a diameter of $<5 \mathrm{~nm}$ in upper centre. Below, a group of larger particles, up to $100 \mathrm{~nm}$ in diameter. $\times 100000$.

Fig. 4b Electron micrograph showing a part of a lysosome in an alveolar macrophage. The finely granular background at upper left resembles the smallest particles in welding fume. The larger particles (white arrows) are very similar to those in Fig. $4 a$. A curved chain is seen at upper right (black arrow). Uranyl acetate and lead citrate, $\times 100000$

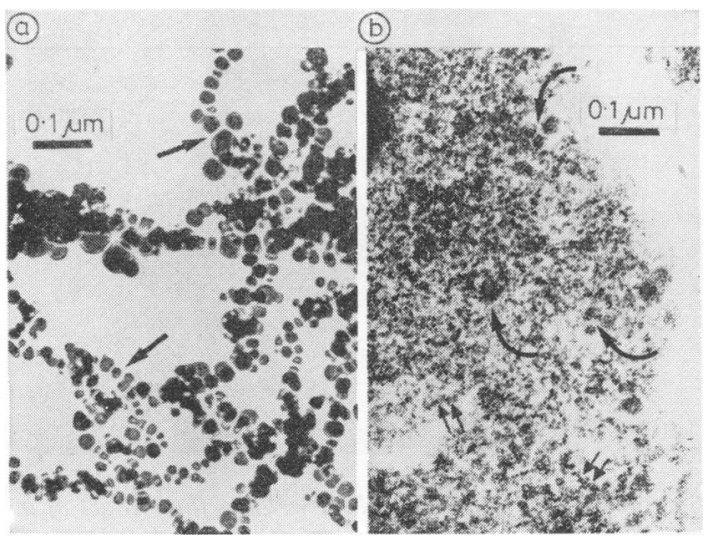

Fig. 5a Electron micrograph of welding fume showing particles with a diameter of 10-50 nm arranged in chains. Several particles seem to be made of smaller subunits (arrows). $\times 100000$.

Fig. 5b Electron micrograph showing a part of a lysosome in an alveolar macrophage. Roundish particles consisting of smaller subunits of the same size range as those in Fig. 5a are marked with curved arrows. Short chains (double small arrows, below) are visible on a finely granular background. Uranyl acetate and lead citrate, $\times 100000$.
$190 \times 10^{-6}$ (MKSA units) and from 310 to $700 \mathrm{ppm}$ respectively. By measuring the magnetic saturation polarisation of welding fume, the magnetite concentration of the welding-fume sample was found to be $27.4 \%$ by weight. Thus the concentration of welding fumes varied from 1100 to $2600 \mathrm{ppm}$ which is 300 700 times higher than that of tissue from the unexposed subject.

\section{Measurement of permanent magnetic fields}

The average magnetic field $\overline{(B)}$ measured from the welder's lungs was $0.74 \mathrm{nT}$ (nano tesla) and the corresponding amount of welding-fume contaminants in the lungs was $110 \mathrm{mg}$.

Fig. 6 presents a typical contour map of the permanent magnetic field measured from one slice (No. 5), cut from the right lung in the sagittal direction. Radiological opacities (Fig. 1) caused by contaminants correlated well with the results of magnetic measurements.

Fig. 7 shows the relative amounts of contaminants in each slice of the welder's lung, cut frontally. Contaminants tended to be deposited in the central regions of the lungs. Two concentration centres could be seen in each lung, one anterior and one posterior. The intensity of the posterior contamination centre was about twice as great as that of the anterior centre. Fifty-two per cent of the total contaminants were distributed in the right lung and $48 \%$ in the left lung.

\section{Discussion}

The subject whose lungs were studied in this investigation was a 34-year-old non-smoking male mild steel arc welder, who had worked in a single shipyard for a total of 11 years. The material he welded and the electrodes he used had varied very little during this period. He had been healthy, without any respiratory symptoms, and a routine chest radiograph had been interpreted as showing no siderotic changes two weeks before he died from myocardial infarction. The characteristics of mild steel manual arc welding fumes have been described earlier (Virtamo et al., 1975; Stern, 1976) and our own electron micrographs of the welding fume were remarkably similar to those of the previous authors.

The spatial distribution of contaminants in both lungs was studied by three different methods: lung slices were examined by eye and by radiography, while magnetic measurements were made both on slices and on intact fixed lungs. There was a good correlation between the methods used, which all showed that there was a tendency for deposition of particles in the central regions of the lungs, forming two concentration centres, one in front of, and the other behind, the hilum. The posterior centre con- 
Table 1 Concentration in ppm of $\mathrm{Fe}, \mathrm{Mn}, \mathrm{Mg}, \mathrm{Cr}, \mathrm{Ni}, \mathrm{Cu}, \mathrm{Zn}$ in freeze-dried lungs, analysed from slice $\mathrm{No} .2$ from the right lung and from slices Nos. 2, 3, 6, 10 from the left lung of the arc welder

\begin{tabular}{|c|c|c|c|c|c|c|}
\hline \multirow[t]{2}{*}{ Element } & \multicolumn{5}{|c|}{ Arc welder's lungs } & \multirow{2}{*}{$\begin{array}{l}\text { Average concentration } \\
\text { and standard deviation } \\
\text { of elements in lungs of } \\
\text { unexposed subjects* }\end{array}$} \\
\hline & $\begin{array}{l}\text { Slice No. } 2 \\
\text { right lung }\end{array}$ & $\begin{array}{l}\text { Slice No. 2; } \\
\text { left lung }\end{array}$ & $\begin{array}{l}\text { Slice No. 3; } \\
\text { left lung }\end{array}$ & $\begin{array}{l}\text { Slice No. } 6 \\
\text { left lung }\end{array}$ & $\begin{array}{l}\text { Slice No. 10; } \\
\text { left lung }\end{array}$ & \\
\hline $\begin{array}{l}\mathrm{Fe} \\
\mathrm{Mn} \\
\mathrm{Mg} \\
\mathrm{Cr} \\
\mathrm{Ni} \\
\mathrm{Cu} \\
\mathrm{Zn}\end{array}$ & $\begin{array}{c}7030 \\
54 \cdot 4 \\
124 \\
9 \cdot 8 \\
8 \cdot 2 \\
64 \cdot 9 \\
73 \cdot 9\end{array}$ & $\begin{array}{l}4950 \\
12.3 \\
97 \\
\text { not detected } \\
\text { not detected } \\
28.6 \\
48.5\end{array}$ & $\begin{array}{c}5340 \\
10.6 \\
81 \\
\text { not detected } \\
\text { not detected } \\
16.7 \\
52.5\end{array}$ & $\begin{array}{c}5610 \\
15 \\
92 \\
2 \cdot 1 \\
<6 \\
13 \cdot 6 \\
27 \cdot 3\end{array}$ & $\begin{array}{c}4350 \\
21 \\
86 \\
5 \cdot 8 \\
14 \cdot 4 \\
24 \cdot 0 \\
38 \cdot 2\end{array}$ & $\begin{array}{l}1148 \pm 464 \\
1.35 \pm 1.08 \\
- \\
\sim 1 \\
\sim 1 \\
6.8 \pm 2.4 \\
67.2 \pm 8.4\end{array}$ \\
\hline
\end{tabular}

* Reference values based on results from Vuori et al. (1975).

Table 2 Concentration of magnetite and welding-fume of cadaver lung as ppm of freeze-dried lungs

\begin{tabular}{|c|c|c|c|}
\hline $\begin{array}{l}\text { Slices of the welder's } \\
\text { left lung and of a } \\
\text { lung from an } \\
\text { unexposed subject }\end{array}$ & $\begin{array}{l}\text { Magnetic } \\
\text { susceptibility } \\
\left(10^{-6} M K S A\right. \\
\text { units) }\end{array}$ & $\begin{array}{l}\text { Magnetite } \\
\text { concentration } \\
(\text { ppm })\end{array}$ & $\begin{array}{l}\text { Fume } \\
\text { concentration } \\
(\text { ppm })\end{array}$ \\
\hline \multicolumn{4}{|l|}{ Cadaver } \\
\hline slice No. 2 & 108 & 390 & 1400 \\
\hline slice No. 3 & 82 & 310 & 1100 \\
\hline slice No. 4 & 190 & 700 & 2600 \\
\hline slice No. 10 & 95 & 340 & 1300 \\
\hline \multicolumn{4}{|l|}{ Slice of lung from } \\
\hline unexposed subject & $<0.3$ & $<1$ & $<4$ \\
\hline Fume & & 274000 & 1000000 \\
\hline
\end{tabular}

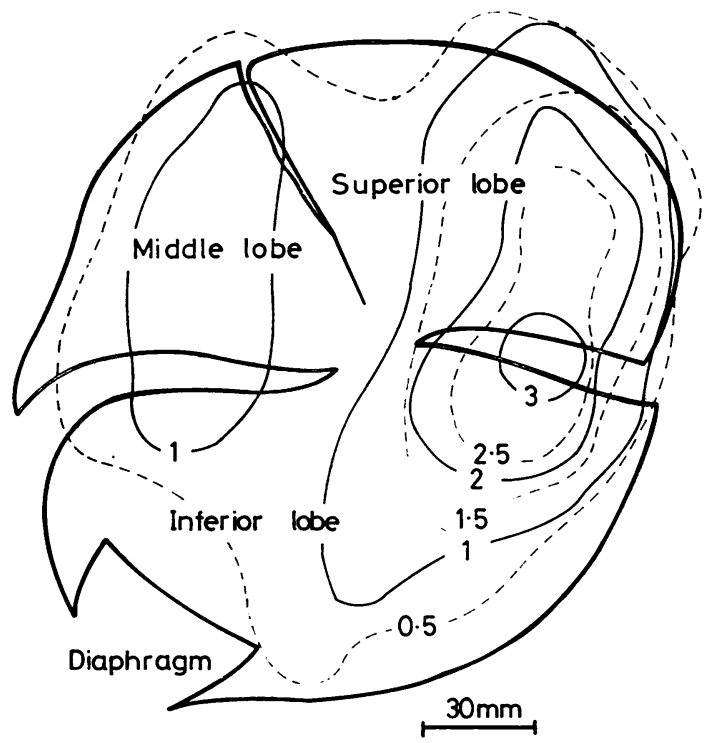

Fig. 6 Contour map of the measured permanent magnetic field $(n T)$ measured in one slice (No. 5 , thickness $10 \mathrm{~mm}$ ) taken from the right lung in a sagittal direction. The measuring distance was about $20 \mathrm{~mm}$.

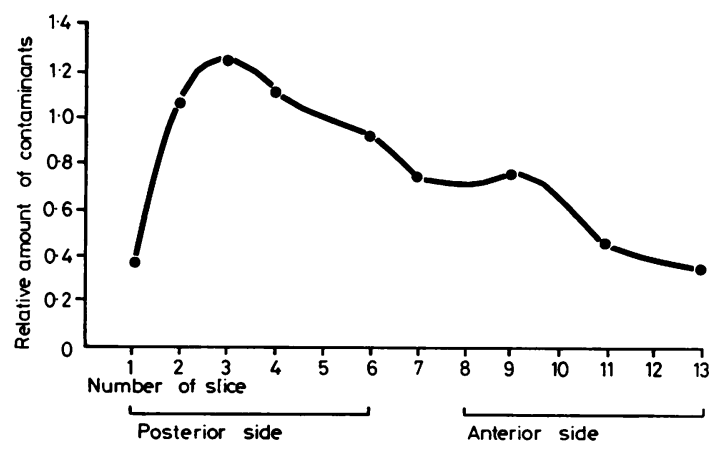

Fig. 7 The relative amounts of contaminants in each slice of the welder's left lung, cut coronally, showing two concentration centres, one anterior and one posterior.

tained twice the concentration of contaminating material present in the anterior centre. Measurements in living welders have shown a similar distribution of contaminants, with individuals varying in the preponderance of deposition anteriorly or posteriorly (Kalliomäki, 1977; Kalliomäki et al., 1978). This variability is apparently dependent on the distribution of maximal ventilation per unit of lung volume (as demonstrated radiospirometrically by Korhonen in 1974).

The histological examination showed pigmented macrophages in the air spaces and interstitium close to the centre of the acinus, with slight fibrosis around pigment deposits, but no emphysema. This observation is in agreement with previous studies (Harding et al., 1958; Morgan and Kerr, 1963).

Transmission electron micrographs of the alveolar macrophages displayed lysosomal material which was strikingly similar to the roundish particles of different sizes in the welding fume. Even the arrangement in chains was preserved to some extent in the phagocytosed material. Future studies with the scanning electron microscope and microprobe analyser 
(Stettler et al., 1977) may reveal the nature of this material.

We determined the concentration of lung contaminants by measuring the susceptibility, and the amount by measuring the remanent magnetic field. These highly sensitive methods were necessary because the materials were present in such low concentrations. Both methods gave similar results. The total amount of contaminants, $110 \mathrm{mg}$, was much less than the average value $(700 \mathrm{mg})$ for welders in the same shipyard measured during life (Kalliomäki, 1977; Kalliomäki et al., 1978).

Comparison of Tables 1 and 2 suggests that inhaled iron represents only $10 \%$ of the total iron found chemically in lung tissue. The total iron concentration in our welder was, at most, only 10 times higher than that in control tissue. Other authors have found much higher values for total iron (Mann and Lecutier, 1957; Angervall et al., 1960; Morgan and Kerr, 1963; Meyer et al., 1967; Hewitt and Hicks, 1973). These analyses, however, have included endogenous iron, which tends to increase in the presence of retained lung contaminants (Casswell et al., 1970). Thus the determination of exogenous iron by chemical methods is, at present, an almost impossible task. However, as it is only the inhaled iron which is magnetic, measurements of the magnetic properties provide an easy solution to this problem.

\section{References}

Angervall, L., Hansson, G., and Röckert, G. (1960). Pulmonary siderosis in electrical welder. Acta pathologica et microbiologica scandinavica, 49, 373-380.

Buckup, H. (1973). Die Schweisserlunge-differente oder indifferente Lungenveränderungen. Zentralblatt für Arbeitsmedizin und Arbeitsschutz, 23, 286-293.

Casswell, C., Bergman, I., and Rossiter, C. E. (1970). The relation of radiological appearance in simple pneumoconiosis of coal miners to the content and composition of the lung. In Inhaled Particles III, volume 2, pp. 713-721. Edited by W. H. Walton. Unwin Brothers: Old Woking, Surrey.

Charr, R. (1955). Respiratory disorders among welders. American Review of Tuberculosis and Pulmonary Diseases, 71, 877-884.

Charr, R. (1956). Pulmonary changes in welders: a report of three cases. Annals of Internal Medicine, 44, 806-812.

Cohen, D. (1973). Ferromagnetic contamination in the lungs and other organs in the human body. Science, 180, 745-748.

Cohen, D. (1975). Measurements of the magnetic fields produced by the human heart, brain, and lungs. IEEE Transactions on Magnetics, MAG-11: 2, 694-700.

Curry, L. A. (1968). Limits for qualitative detection and quantitative determination. Analytical Chemistry, 40, 586-593.

Einbrodt, J. J., Maass, W., Josten, H.-G., and Stecher, W. (1971). Untersuchungen über die Lungenveränderungen bei Elektroschweissern. Offentliche Gesundheitswesen, 33, 286-299.

Enzer, N., and Sander, O. A. (1938). Chronic lung changes in electric arc welders. Journal of Industrial Hygiene, 20, 333-350.

Friede, E., and Rachow, D. (1961). Symptomatic pulmonary diseases in arc welders. Annals of Internal Medicine, 54,
121-127.

Harding, H. E., McLaughlin, A. I. G., and Doig, A. T. (1958). Clinical, radiographic and pathological studies of the lungs of electric arc and oxyacetylene welders. Lancet, 2, 394-398.

Hewitt, P. J., and Hicks, R. (1973). An investigation of the effect of inhaled welding fume in the rat. Annals of Occupational Hygiene, 16, 213-221.

Kalliomäki, P.-L. (1977). Measurement of Magnetic Lung Contamination in vivo. Evaluation of the Method and its Application to Arc Welders. Academic Dissertation: Institute of Occupational Health, Helsinki.

Kalliomäki, P.-L., Alanko, K., Korhonen, O., Mattsson, T., Vaaranen, V., and Koponen, M. (1978). Amount and distribution of welding fume lung contaminants among arc welders. Scandinavian Journal of Work, Environment and Health, 4, 122-130.

Kalliomäki, P.-L., Korp, P., Katila, T., Mäkipää, P., Saar, P., and Tossavainen, A. (1976). Magnetic measurements of pulmonary contamination. Scandinavian Journal of Work, Environment and Health, 4, 232-239.

Korhonen, O. (1974). ${ }^{133}$ Xenon Radiospirometry with Moving Detectors. Academic Dissertation: Institute of Occupational Health, Helsinki.

Laurila, E. (1961). On the magnetic permeability of mixtures containing ferromagnetic materials. Annales Academiae Scientiarum Fenniae, Ser. A VI, Physica, 70.

Laurila, E. (1976). On the use of sat magan as a Gouy balance and as an instrument for the distinction between the ferromagnetic and paramagnetic susceptibility of minerals. Acta Polytechnica Scandinavica, Physics Including Nucleonics, 114.

McDowell, E. M., and Trump, B. F. (1976). Histologic fixatives suitable for diagnostic light and electron microscopy. Archives of Pathology and Laboratory Medicine, 100, 405-414.

Mann, B. T., and Lecutier, E. R. (1957). Arc welders' lung. British Medical Journal, 2, 921-922.

Meyer, E. C., Kratzinger, S. F., and Miller, W. H. (1967). Pulmonary fibrosis in an arc welder. Archives of Environmental Health, 15, 462-469.

Morgan, W. K. C., and Kerr, H. D. (1963). Pathologic and physiologic studies of welders' siderosis. Annals of Internal Medicine, 58, 293-304.

Shandley, P. D., and Bacon, L. O. (1966). Analysis for magnetite utilizing magnetic susceptibility. Geophysics, 31, 398-409.

Slepička, J., Kadlec, K., Tesař, Z., Škoda, V., and Miřejovsky, P. (1970). Beitrag zur Problematik der Elektroschweisserpneumokoniose. Internationales Archiv für Arbeitsmedizin, 27, 257-280.

Stern, R. (1976). Production and characterization of a reference standard welding fume. Rapport SVC: Köpenhagen.

Stettler, L. E., Broth, D. H., and Mackay, G. R. (1977). Identification of stainless steel welding fume particulates in human lung and environmental samples using electron probe microanalysis. American Industrial Hygiene Association Journal, 38, 76-82.

Weissberger, A., and Rossiter, B. E. (1972). In Techniques of Chemistry, Vol. 1, part 4, pp. 504-519. Wiley: New York.

Virtamo, M., Tossavainen, A., and Ruishalme, J. (1975). Valimoaineet. Työterveyslaitoksen tutkimuksia no 109 , Työterveyslaitos.

Vuori, E., Huunan-Seppälä, A., and Kilpiö, J. O. (1975). The concentration of copper, iron, manganese, zinc and cadmium in human hair as a possible indicator of their tissue concentrations. In International Symposium Proceedings: Recent Advances in the Assessment of the Health Effects of Environmental Pollutants. Luxembourg 1975, Vol. IV, pp. 2263-2270. 